\title{
Frederic Renner and Charlie Russell SRM Legacy
}

\section{By Tamra L. DeCock}

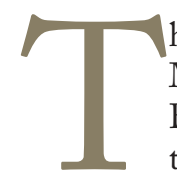
he theme of the upcoming 2011 SRM Annual Meeting in Billings, Montana, is "Transcending Borders-Landscapes and Legends." With this theme in mind, I would like to take the opportunity to highlight two SRM legends with their roots in Montana: Frederic G. Renner and Charlie Russell. Frederic Renner was a founding member of SRM, the second President of the Society, and SRM's first life member. Frederic Renner knew artist Charlie Russell and promoted SRM's logo "The Trail Boss" from Charlie's pen and ink original. ${ }^{\mathrm{i}}$

In 1949 Society Secretary W. James Anderson suggested the need for an SRM emblem. When Renner received a typewritten copy of the 1950 Annual Meeting program for printing, he attached a photograph of "The Trail Boss" to the program, instructing the printer to reproduce it in the center of the front cover. This was the first use of "The Trail Boss" in SRM materials. It inspired so many favorable comments that the SRM Board of Directors obtained permission to use it as the Society's emblem. Renner said the drawing "had long symbolized qualities that it occurred to me were partially appropriate to our newly formed Society: the importance of strong leadership, the necessity of all hands working together and a willingness to travel unchartered trails." 1

Charlie Russell's "The Trail Boss" shows a typical landscape found in the northern Great Plains-table top buttes, bunchgrass, and sagebrush. Charlie Russell often included a generous amount of landscape in his art work. I believe this is one of the reasons Charlie Russell so proficiently captured the spirit and culture of the west. Landscapes compel a person to feel part of a bigger picture. Man is part of the ecosystem, and the ecosystem defines, in part, the person he is. Often as people view sights such as the Grand Canyon or the vast landscapes of the northern Great Plains,

\footnotetext{
The original of "The Trail Boss" was in pen and ink; however, somewhere along the line the original was watercolored over. According to Renner it was not watercolored by Charlie Russell and was very poorly done. SRM does not own the original "The Trail Boss," this being one of the reasons.
}

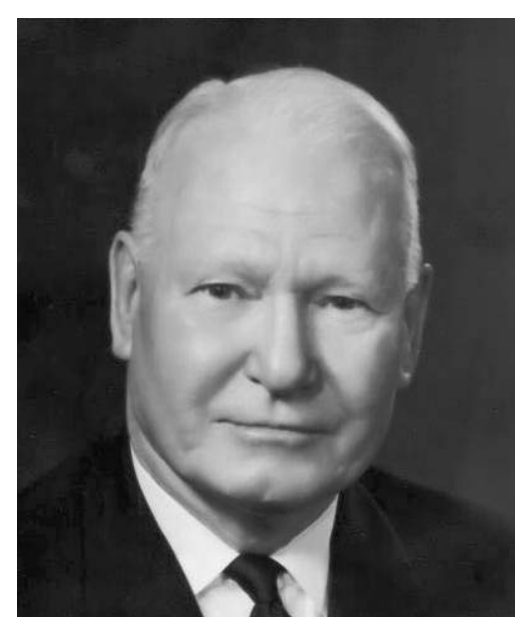

Frederic Renner.

they are impacted by a powerful understanding of man's interconnectivity and significance to landscapes and ecosystems. "The Trail Boss" portrays the trail boss as part of a unified effort, united with the landscape/ecosystem and ready to meet the challenges ahead.

As Tim Ross stated,

The Trail Boss is in charge of the well-being of the cattle, horses, people, and yes the range. Adopted as a symbol of care-as I believe Charlie Russell drew bim, "The Trail Boss" is a symbol that we as members of SRM are stewards of range lands. ${ }^{2}$

Fredric Renner was born in Great Falls, Montana. Fredric Renner's parents were friends of Nancy Russell before she married Charlie Russell. This gave Fred, a first grader, trespassing privileges in the Russell home and watching rights in Charlie's log cabin studio. "Charlie loved kids," Renner recalled,

and if I was alone, I'd go in and watch him work. But if there were two or three of us, Mrs. Russell would herd us out of the place. But if she didn't know we were there and we kept quit, Charlie would let us watch. I can still see him turning around, looking at us with a grin, and shouting, "Well, how do you like it?"3 


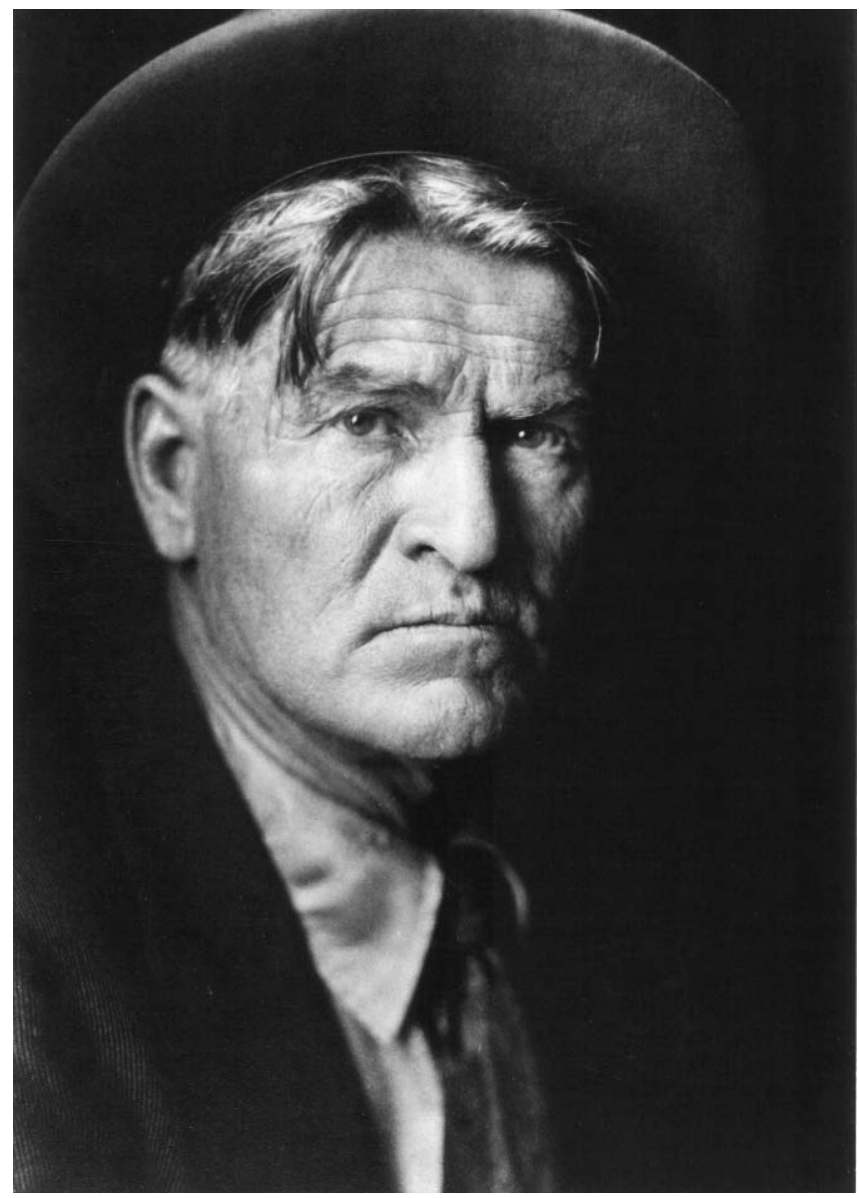

Charlie Russell. Photo taken by H. Pollard, September 1912, Calgary, Alberta, Canada.

Renner graduated from the University of Washington College of Forestry, where he studied forestry and animal husbandry and became a National Forest administrator in Oregon in 1916. In 1928 he moved to the Great Basin Station as a range scientist and started studies in the Boise Basin, where he worked until 1936. In Fredric Renner's early career, like most of the first range scientists, he focused his research on the link between overgrazing and soil erosion. He worked across much of the over-stressed rangeland in the southern part of the Boise National Forest, living in tents or at Forest Guard Stations near study areas. Renner surveyed soil conditions and factors relating to erosion in the late 1920s on about 370,000 acres of land between the Middle and South Forks of the Boise River. ${ }^{1}$

Forest Service photos of Renner's early career showed landscapes gouged with massive gullies. One photo shows a Forest Service employee in the bottom of a recently eroded channel; even standing on top his horse, with his feet in the saddle, the top of the channel was beyond his reach. Renner observed firsthand the devastation that improper use of our rangelands can cause, what most only read about today.

Renner pioneered snow survey work as part of his range watershed research and was especially proud of having planned and conducted the first scientific snow survey.

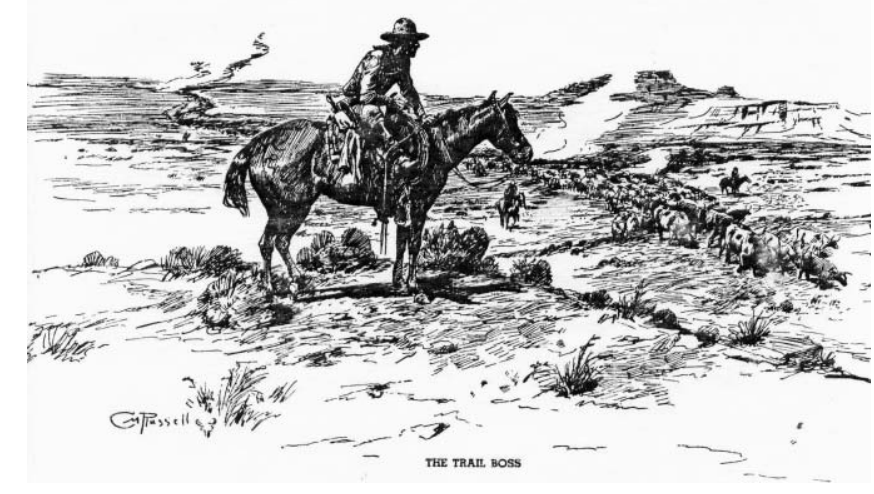

"The Trail Boss."

Renner moved to the California Experiment Station, where he supervised the creation of the San Joaquin Experimental Range. Here he wrote a comprehensive technical bulletin on erosion in the Boise River watershed. ${ }^{4}$ Then he left the Forest Service to work for the Soil Conservation Service. ${ }^{1}$

Renner spent the last 25 years of his professional career with the Soil Conservation Service. He retired in 1961 after his 25th year as Chief of the Range Conservation Division of the Soil Conservation Service. Renner provided technical oversight for the quantitative ecological approach method in rating range condition. He was instrumental in bringing all interests together to solve range problems, as there was more competition than cooperation among the federal agencies. Mr. Renner worked hard to standardize procedures in all agencies and to encourage full rancher participation in the Society. Renner had an abiding love for the land of the western United States and a deep feeling that the land should not be desecrated by overpopulation, overgrazing, or attempted farming on land that had no tolerance for the plow. Using scientific methods, his professional career was devoted to introducing ideas and practices that would allow the land to recover from devastating grazing and farming practices.

Renner had accumulated an impressive collection of distinguished achievement awards for his leadership in designing the innovative and practical range improvement programs that were widely adopted by ranchers. One of Renner's proudest possessions, however, was his "Outstanding Achievement Award" from the SRM. ${ }^{3}$ In 1971 Fred Renner offered a cash gift to SRM to be used for the establishment of the Frederic G. Renner Award. This award was to be given annually for significant and outstanding accomplishments in the field of range management and is one of the highest honors bestowed by SRM. The first Renner Award was given in 1972 to Peter V. Jackson III.

Renner pursued his range conservation work with great zeal, and he was equally relentless about his art collection hobby, which became a full-time occupation after he retired 


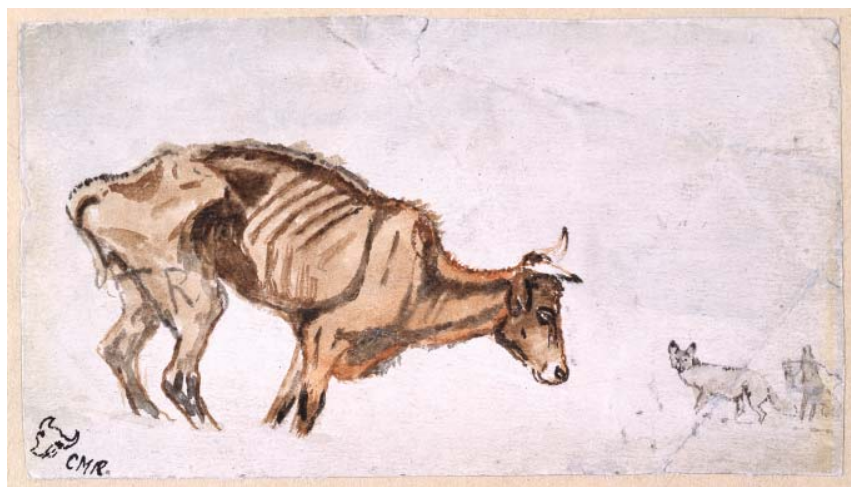

Waiting for a Chinook-"The Last of 5000," sketch by Charlie Russell. Used with permission from the Montana Stockgrowers Association, Helena, Montana, USA.

from the Soil Conservation Service. Renner wrote Charles M. Russell, ${ }^{5}$ the book Russellphiles consider the most authoritative ever written about the works of the legendary artist. Few original Russell works were purchased during Renner's lengthy lifetime without his authentication. Collectors, auction houses, dealers, museums, and many others wanted his opinion before buying. Renner's opinions were backed by a huge photo collection and library that he spent decades assembling. He also assembled one of the largest personal collections of Russell works. The Frederic G. Renner Library in the C. M. Russell Museum at Great Falls, Montana, is a research library dedicated to the study of western art and Charles Russell's creations. ${ }^{6}$

Charlie Russell was born to an affluent family in St. Louis, Missouri. Although he was a well-bred Easterner with inherited social station, he did not take a liking to school and had a desire to see the real west as depicted in dime store novels. He traveled to the Montana territory in 1880 when he was 16 years old. Charlie had lit out for the pristine frontier, but the railroads had arrived ahead of him. He loved and embraced the open landscapes and the western lifestyle, and he made Montana his home.

Gold was discovered 1862 at Bannack in southwestern Montana. The battle at the Little Big Horn between General Custer, the Sioux, and Cheyenne happened in 1876, just four years before Charlie arrived in Montana. Then in 1877, Chief Joseph's Nez Perce run ended in northern Montana with Joseph's concession, "I will fight no more forever." Charlie Russell died in 1926.

The period in which Charlie Russell lived in Montana was a time when rangelands were being grazed aggressively and the numbers of cattle and sheep were rapidly increasing. Charlie cared about the country and what was happening to it. Charlie Russell characterized the west with his sketches and paintings. "Waiting For A Chinook," also called "The Last of 5000," was sketched by Charlie Russell after the devastating winter of 1886-1887, when over 300,000 livestock lay dead across the plains before spring.

Concern for our rangeland resources was on the rise. SRM was formally organized as the American Society for
Range Management at a meeting in Salt Lake City, Utah, in January 1948. Frederic Renner was president of SRM in 1949-1950 and saw membership double from 750 to 1,500 members. Men were ready to meet the challenges just like those depicted in "The Trail Boss."

Our logo is held dear by SRM members, and those inherent qualities of a trail boss are still important today. Fee Busby, SRM President in 1986-1987, recently shared with me his thoughts on "The Trail Boss":

\section{I have always thought of the Trail Boss as being the rangeland manager who was just like the person depicted by Charlie Russell, responsible for figuring out how the range ecosystem worked and then manage the uses to sus- tain the productive capacity of the land. In other words, what's important about the logo is not the era or time depicted but the person-a leader, in charge, dedicated to developing and implementing a workable rangeland management plan.}

Today the Northern Great Plains still has wide open landscapes. But today these landscapes are crisscrossed with wire fences and blessed with improved grazing practices. Hence rangelands are depended upon and enjoyed by many.

As stewards of rangeland ecosystems we are challenged today with multiple and numerous uses that must be balanced and properly applied. Science in combination with an attitude of caring for the people, plants, and animals who depend on these resources is required. I believe SRM members have the leadership and dedication to successfully meet these challenges.

\section{References}

1. KLADE, R. J. 2006. Building a research legacy: the intermountain station 1911-1997. RMRS-GTR-184. Fort Collins, CO, USA: US Forest Service Rocky Mountain Research Station. $259 \mathrm{p}$.

2. Ross, T. 2003. Rangelands and rainbows. Rangelands 25(5): 3-5.

3. Chohlis, J. 1976. Fred Renner. In: I Believe. Oklahoma City, OK, USA: National Cowboy and Western Heritage Museum. p. 63-75.

4. Renner, F. G. 1936. Conditions influencing erosion on the Boise River Watershed. Technical Bulletin 528. Washington., DC, USA: US Department of Agriculture. 31 p.

5. Renner, F. G., And C. M. Russell. 1966. Paintings, drawings and sculpture in the Amon G. Carter collection. Austin, TX, USA: University of Texas Press, with the Amon Carter Museum, Forth Worth. 296 p. Subsequent editions published by Harry N. Abrams, New York, NY, USA.

6. Chонlis, J. 1980. The wide and colorful range of Fred Renner. Rangelands 2(2):47-50.

Author is Rangeland Management Specialist, USDA-Natural Resources Conservation Service, Miles City, MT 59301, USA, Tammy.Decock@mt.usda.gov. 